\title{
Analisis Sloshing 2D pada Dinding Tangki Tipe Membran Kapal LNG Akibat Gerakan Rolling di Gelombang Regular
}

\author{
Ericson Estrada Sipayung, I Ketut Suastika, Aries Sulisetyono \\ Jurusan Teknik Perkapalan, Fakultas Teknologi Kelautan, Institut Teknologi Sepuluh Nopember (ITS) \\ Jl. Arief Rahman Hakim, Surabaya 60111 Indonesia \\ e-mail: k_suastika@na.its.ac.id
}

\begin{abstract}
Abstrak----Pemakaian kapal sebagai sarana distribusi LNG ke berbagai wilayah merupakan salah satu cara yang menguntungkan dan efisien. Penggunaan kapal sebagai sarana distribusi LNG membuat hal-hal yang berhubungan dengan tangki kapal menjadi menarik untuk diteliti. Salah satu yang paling banyak diteliti adalah fenomena sloshing. Simulasi gerakan fluida pada tanki dilakukan dalam timedomain. Gelombang pada saat kapal berlayar di laut tidak dapat diprediksi dengan akurat. Gelombang yang datang dengan sudut hadap $90^{\circ}$ (beam sea) dapat menimbulkan gerakan rolling yang sangat berpengaruh pada gerakan fluida di dalam tangki atau sering disebut fenomena sloshing. Gerakan fluida ini menimbulkan gaya berupa tekanan pada dinding tangki berupa dynamic pressure. Tangki jenis membrane banyak digunakan pada kapal LNG. Sehingga, banyak penelitian yang berkaitan dengan tangki membrane. Tangki membrane dimodelkan 3D dengan menggunakan software maxsurf yang berukuran panjang $32.46 \mathrm{~m}$, tinggi $27.32 \mathrm{~m}$ dengan lebar moulded belakang $39.17 \mathrm{~m}$, lebar belakang bagian bawah $31.29 \mathrm{~m}$, lebar belakang bagian atas $31.29 \mathrm{~m}$. lebar moulded depan $39.17 \mathrm{~m}$, lebar depan bagian bawah $31.29 \mathrm{~m}$, lebar depan bagian atas $31.29 \mathrm{~m}$. Volume cairan LNG divariasikan dengan 3 (tiga) ketinggian yaitu ketinggian cairan $30 \%$ dari tinggi tangki, $50 \%$ dari tinggi tangki, dan $\mathbf{8 0 \%}$ tinggi tanki. Analisa dilakukan dengan menggunakan software Ansys Fluent dengan metode Computational Fluid Dynamic (CFD). Dari hasil analisa dengan ansys fluent dapat disimpulkan bahwa dynamic pressure terbesar terjadi pada filling level $30 \% \mathrm{H}$ dalam tanki yaitu sebesar 16513.720 Pa yang terjadi pada bagian kanan dinding tanki pada ketinggian 8,655 m dari dasar tanki.
\end{abstract}

Kata Kunci : Rolling, CFD Fluent, Tanki Membrane, Kapal LNG, Sloshing

\section{PENDAHULUAN}

$\mathrm{M}$ ANUSIA dan energi mempunyai hubungan yang sangat erat. Manusia sampai dengan revolusi industri hanya menggunakan sebagian kecil energi yang ada di alam yang disebut energi terbarukan (renewable energy). Sejak revolusi industri, dimungkinkan pemakaian energi dalam jumlah besar yang berasal dari batu bara. Memasuki abad 20 pemakaian energi minyak bumi semakin meluas, dan akhir-akhir ini gas alam dan tenaga nuklir telah dimanfaatkan untuk menopang kebutuhan energi dalam jumlah besar. Masa setelah revolusi industri dapat disebut sebagai era penggunaan energi atau bahan bakar fosil seperti gas alam, minyak bumi dan batubara dalam jumlah besar, yang sampai saat inipun masih berlanjut. Meningkatnya taraf hidup manusia dan besarnya tuntutan terhadap kepraktisan dan kenyamanan hidup membuat kebutuhan terhadap energi semakin besar. Dengan demikian, dibutuhkan sumber energi yang besar pula. Liquid Natural Gas (LNG) muncul sebagai salah satu solusi sumber energi yang menjanjikan, karena rasio persediannya masih lebih baik. Pemakaian kapal sebagai sarana distribusi LNG ke berbagai wilayah merupakan salah satu cara yang menguntungkan dan memiliki efisiensi yang cukup baik.

Kekuatan konstruksi kapal dan tangki berkaitan dengan beban gelombang luar yang bersumber dari gelombang air laut akibat gerakan/motion kapal dan juga beban yang ditimbulkan oleh perilaku fluida dalam tangki yang biasa disebut sloshing. Sloshing adalah sebuah fenomena gerakan osilasi yang memukul dinding muatan oleh cairan di dalam sebuah wadah. Dalam menganalisis gerakan sloshing, usaha yang biasanya dilakukan adalah dengan mencegah arah gerakan cairan yang dapat menyebabkan kerusakan pada suatu struktur. Disisi lain, sloshing mempunyai kemampuan dalam mengurangi besarnya energi kinetik ketika kapal melaju. Untuk alasan tersebut, maka analisis gerakan sloshing dilakukan untuk mengetahui karakteristik gerakan sloshing, vector kecepatan sloshing dan arah sloshing yang berhubungan langsung dengan gerakan kapal diakibatkan gelombang regular sehingga dapat diketahui struktur tangki bagian manakah yang memiliki potensi kerusakan terbesar terutama saat gerakan rolling kapal [1].

Prediksi gerakan linier rolling kapal cukup bagus untuk sudut roll yang kecil $<5^{\circ}$. Untuk sudut besar gerakan linier rolling tidak akurat lagi, sehingga harus menggunakan gerakan non linier rolling meskipun penyelesaian agak rumit. Berdasarkan prinsip gerakan linier rolling, setelah kapal mengalami gaya eksitasi maka kapal akan mendapatkan amplitude sesaat, setelah itu karena adanya efek damping kapal akan mengalami osilasi menuju frequensi gelombang. Sedangkan untuk gerakan non linier rolling dengan adanya variasi kecil eksitasi pada titik restoring dapat menyebabkan kapal capsizing dengan kata lain capsizing terjadi pada gerakan non linier rolling, gerakan ini terdiri dari dua komponen non linier yaitu non linier damping dan restoring [2]. 


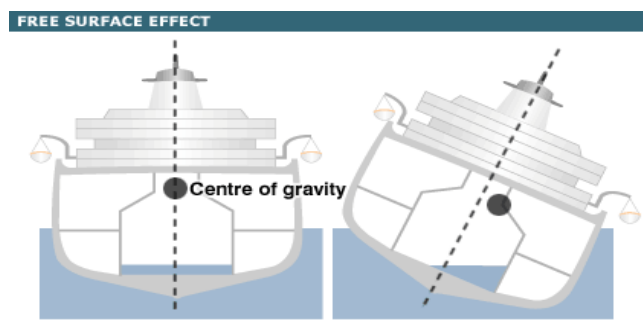

Gambar 1. Ilustrasi gerakan rolling kapal

Kapal yang melaju di permukaan laut memiliki arah gerak berdasarkan arah datangnya gelombang atau biasa disebut Heading, sehingga Heading kapal didefinisikan berdasarkan dari arah propagasi gelombang. Heading angle $(\mu)$ didefinisikan sebagai sudut antara arah kemana kapal melaju dengan arah datangnya gelombang.

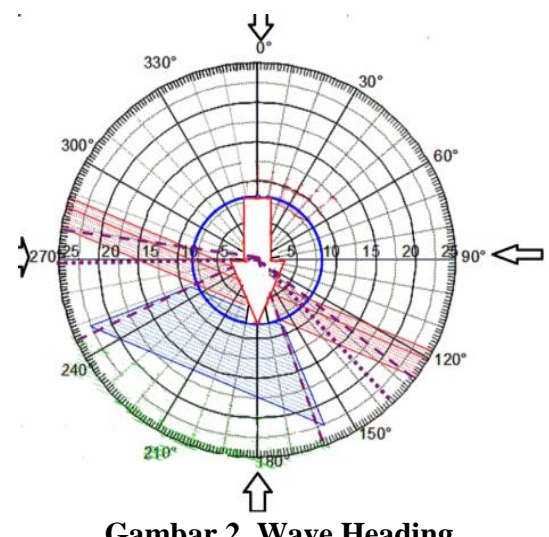

Gambar 2. Wave Heading

Dari gambar diatas dapat dilihat beberapa definisi umum Heading kapal, antara lain:

$\mu=0^{\circ} \quad$ : following waves dimana arah gelombang sama dengan arah kapal.

$\mu=90^{\circ}$ : beam waves dimana gelombang mengenai kapal dari sisi starboard.

$\mu=180^{\circ}$ : heading waves dimana gelombang berjalan berlawanan dengan arah laju kapal.

$\mu=270^{\circ}$ : beam waves dimana gelombang mengenai kapal dari sisi port.

Karena kapal bergerak, maka frekuensi gelombang yang mengenai kapal akan berbeda dengan frekuensi gelombang datang sebenarnya. Fenomena ini terjadi karena adanya gerakan relative dari kapal yang mempunyai kecepatan dengan progresi gelombang. Frekuensi relative ini diistilahkan sebagai frekuensi papasan atau frekuensi encounter [3].

Sloshing merupakan fenomena fisik yang dikarakteristikan adanya gerakan osilasi permukaan bebas fluida pada tangki yang terisi sebagian. Fluida diasumsikan incompressible dan aliranya irrotasional. Sloshing terjadi karena fluida bergerak secara transient/steady pada tangki yang terisi sebagian. Dalam kondisi yang demikian, permukaan bebas liquid bergerak dan menghempas dinding tangki. Sehingga timbul gaya yang membahayakan struktur tangki serta konsekuensi yang tidak diinginkan. Pada pengoperasian kapal sistem tangki harus mempunyai kemampuan berbagai level pengisian tanpa harus terjadi kerusakan yang disebabkan impact pressure akibat sloshing. Liquid dalam tangki yang terisi sebagian mampu menyebabkan terbentuknya pressure yang bekerja pada bagian dinding dan atap tangki. Untuk memprediksi gerakan liquid dan pengaruh pressure terhadap tangki kapal yang terisi sebagian mereka menggunakan pemodelan 2 dimensi.

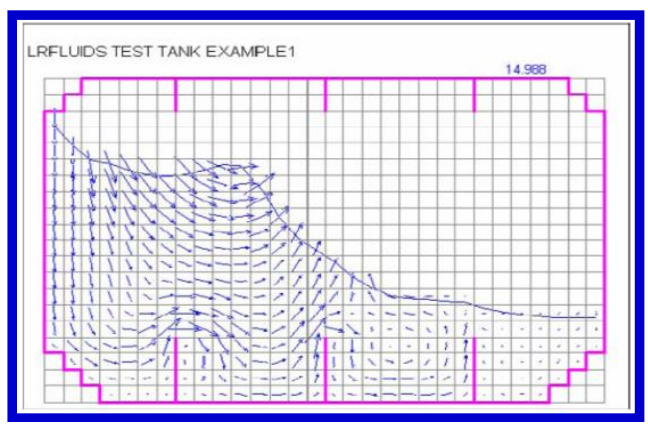

Gambar 3. Visualisasi kecepatan fluida di dalam tangki saat terjadi sloshing

\section{METODE PENELITIAN}

\section{A. Data Spesifikasi Kapal LNG}

Adapun data utama kapal Disha LNG Carrier yang akan disimulasikan adalah sebagai berikut :

Tabel 1. Data ukuran utama kapal [4]

\begin{tabular}{|l|r|l|r|l|}
\hline \multicolumn{5}{|c|}{ Data Kapal LNG Disha } \\
\hline Loa & 277 & $\mathrm{~m}$ & 908.837 & $\mathrm{ft}$ \\
\hline Lpp & 266 & $\mathrm{~m}$ & 872.746 & $\mathrm{ft}$ \\
\hline Lwl & 270.8 & $\mathrm{~m}$ & 888.4948 & $\mathrm{ft}$ \\
\hline $\mathrm{B}$ & 43.4 & $\mathrm{~m}$ & 142.3954 & $\mathrm{ft}$ \\
\hline $\mathrm{H}$ & 26 & $\mathrm{~m}$ & 85.306 & $\mathrm{ft}$ \\
\hline $\mathrm{T}_{\text {Design }}$ & 11.4 & $\mathrm{~m}$ & 37.4034 & $\mathrm{ft}$ \\
\hline $\mathrm{T}_{\text {scantling }}$ & 12.5 & $\mathrm{~m}$ & 41.0125 & $\mathrm{ft}$ \\
\hline Displacement & 100149 & Ton & 3450972.058 & $\mathrm{ft}^{3}$ \\
\hline Deadweight & 70151 & Ton & & \\
\hline$V_{\text {Service }}$ & 19.5 & Knot & 10.0308 & $\mathrm{~m} / \mathrm{s}$ \\
\hline
\end{tabular}

\section{B. Data Lingkungan Pelayaran Kapal}

Untuk menghitung gerakan kapal dibutuhkan data lingkungan pelayaran kapal LNG yang akan dimodelkan. Tujuannya adalah untuk mengetahui secara aktual gerakan kapal yang terjadi yang diakibatkan oleh gelombang terbesar dalam pelayaran kapal tersebut.
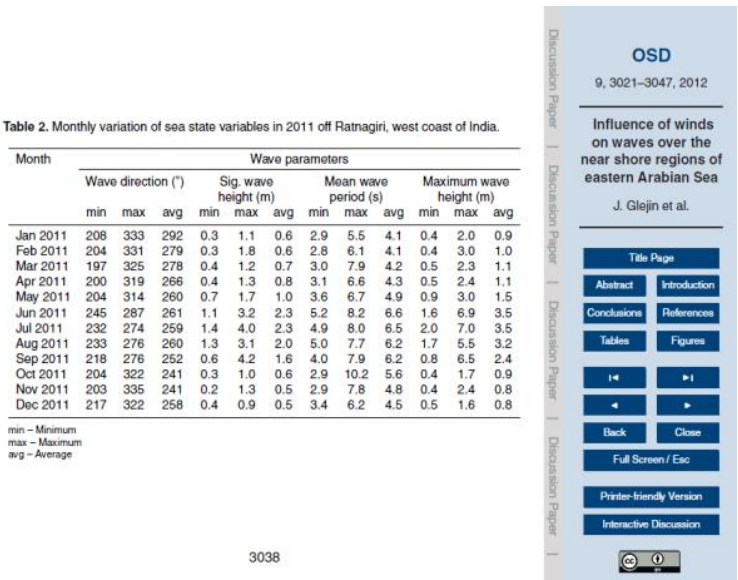

Gambar 4. Data perairan India tahun 2011 


\section{Perhitungan Gerakan Kapal LNG}

Perhitungan gerakan kapal LNG ini dimulai dengan mengimport model kapal yang telah didesain pada software maxsurf ke dalam software seakeeper yang merupakan program integrated dari maxsurf untuk menganalisis gerakan kapal. Software seakeper yang terintegrated bersama maxsurf merupakan software yang dikembangkan oleh formsys dimana perusahaan tersebut adalah salah satu software marine development yang hingga saat ini sudah memproduksi software untuk menganalisa struktur dan bangunan di bidang marine.

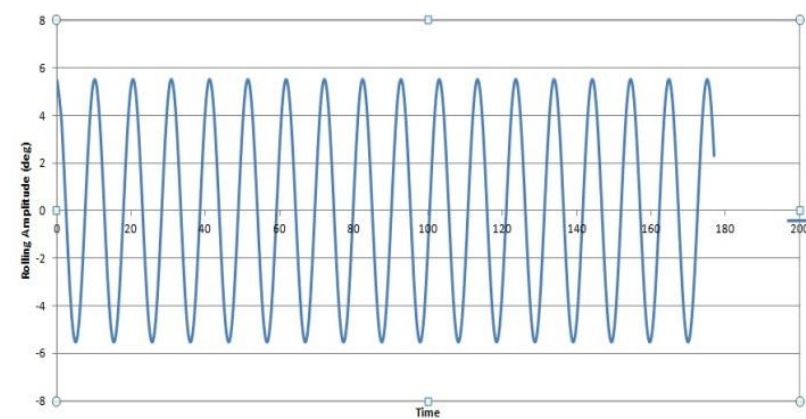

Gambar 5. Time series gerakan rolling kapal pada gelombang regular

Dari hasil output seakeeper didapatkan amplitudo kapal $(\widehat{\Phi})$ sebesar 5.519 deg atau sama dengan 0.09633 . Hasil gerakan kapal LNG tersebut juga merupakan gerakan tangki yang ada didalam Kapal LNG. Sehingga gerakan tangki membrane LNG dapat dihasilkan dengan membuat perbagian masing-masing tangki. Hasil gerakan tersebut kemudian dikonversi kedalam persamaan kecepatan sudut dalam bahasa $\mathrm{C}++$ untuk mendifinisikan gerakan tangki dan dicompile kedalam user define dari program Ansys Fluent. Jadi untuk mendefinisikan kembali gerakan tangki kedalam software ansys fluent persamaan gerakan tersebut adalah :

$\Phi=\widehat{\Phi} * \cos \left(\omega_{\mathrm{e}} * \mathrm{t}\right)$

$\Phi=0.09633 * \cos (0.616 * \mathrm{t})$ sehingga turunan dari persamaan tersebut menjadi:

$\frac{d \Phi}{d t}=-0.09633 * 0.616 \sin \left(0.616^{*} \mathrm{t}\right)$

\section{Pemodelan Tangki Membrane}

Tangki pada studi sloshing ini dimodelkan 3 dimensi (3D) dengan ukuran tangki yang telah didapat dari data kapal LNG dengan lebar $31.29 \mathrm{~m}$, panjang $43.62 \mathrm{~m}$, dan tinggi $27.32 \mathrm{~m}$. Untuk mempermudah pengerjaan model tangki dari maxsurf dibuat lagi di autocad yang kemudian diimport ke ansys fluent dalam bentuk IGES.

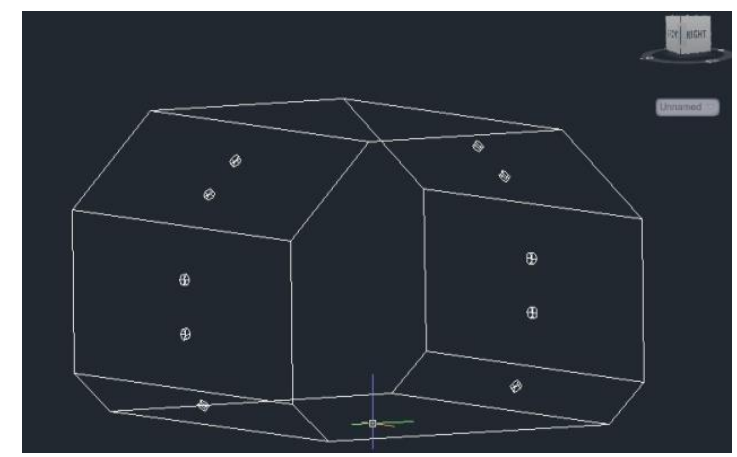

Gambar 6. Model Tangki Pada Autocad

E. Penentuan Node Pressure pada Dinding Tangki

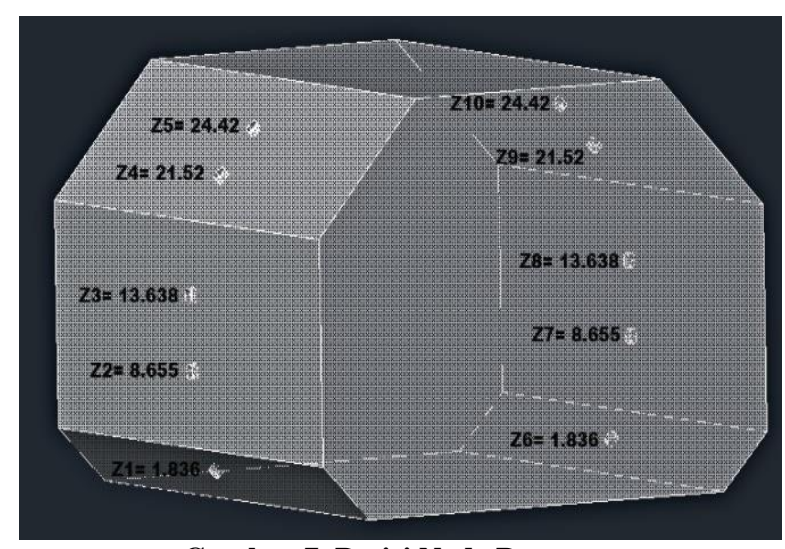

Gambar 7. Posisi Node Pressure

Untuk menentukan letak tekanan terbesar yang terjadi pada dinding tangki tipe membrane NO.96 kapal LNG pada kasus rolling, dibuatlah beberapa titik-titik atau node pada kedua sisi tangki. Letak dari titik-titik ini dibuat secara merata dari tinggi tangki. Tangki yang digunakan pada simulasi ini yaitu tangki nomor 3 dari AP.

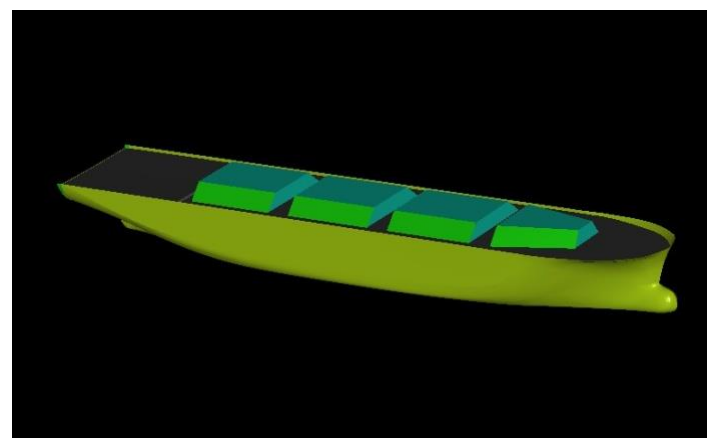

Gambar 8. Posisi Tangki Pada Kapal 


\section{HASIL SIMULASI ANSYS FLUENT}

A. Hasil Perhitungan Pada Tangki Membran Dengan Volume $30 \% \mathrm{H}$
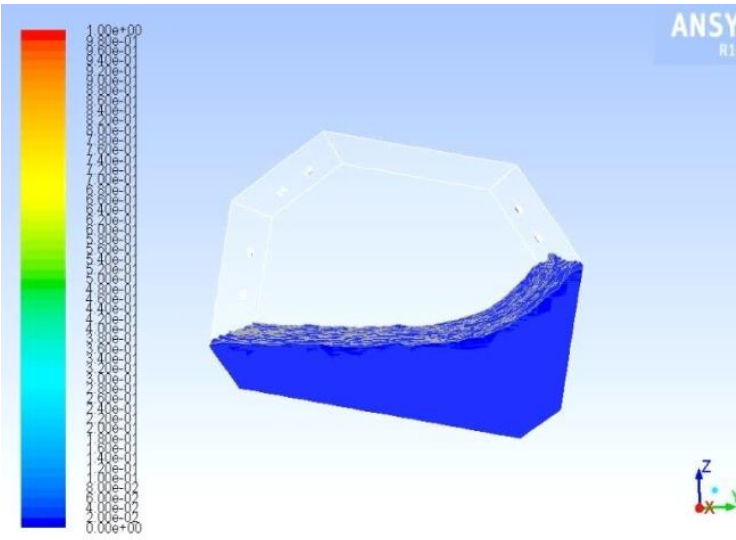

Contours of Volume fraction (cairan) (Time $=1.5421 \mathrm{e}+01)$

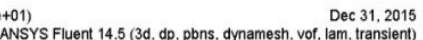

Gambar 9. Snapshot gerakan cairan LNG di dalam tangki pada filling level $30 \% \mathrm{H}$

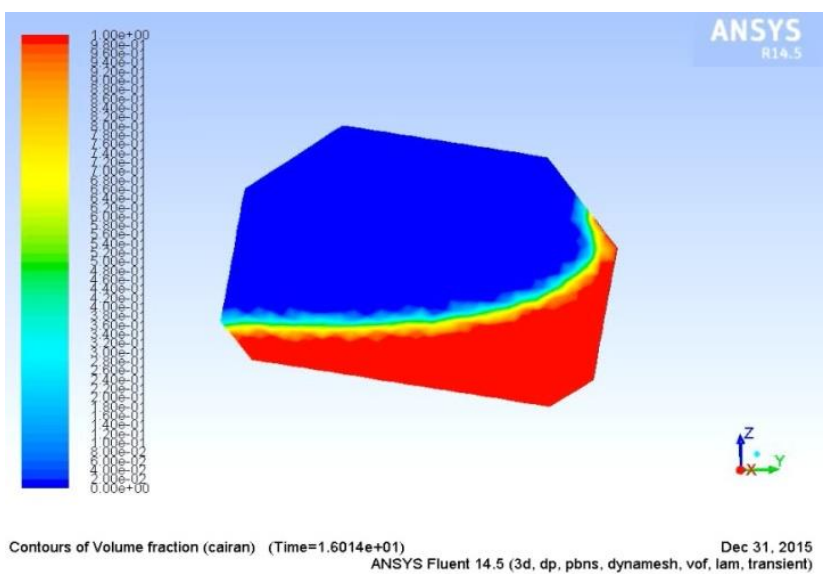

Gambar 10. Kontur dari tekanan dinamis cairan LNG di dalam tangki pada filling level $30 \% \mathrm{H}$

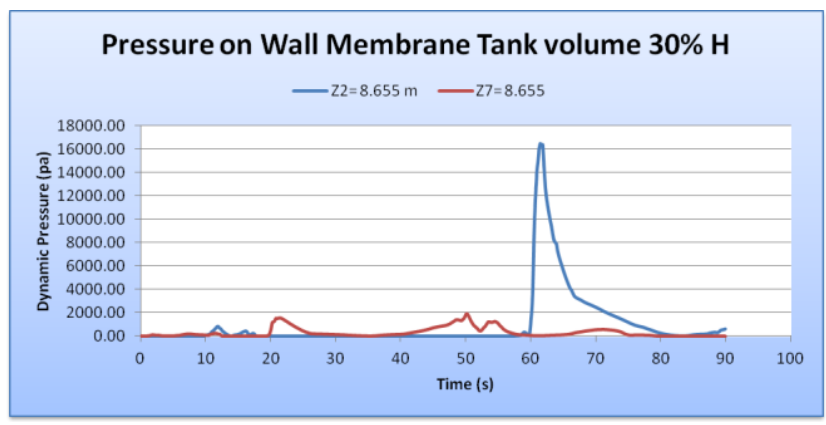

Gambar 11. Time series dari tekanan dinamis cairan LNG pada dinding node $8.655 \mathrm{~m}$ dengan filling level $30 \% \mathrm{H}$

Dari grafik diatas diketahui bahwa tekanan dinamis pada dinding kanan Z2 dan dinding kiri Z7 tangki mempunyai nilai yang berubah - ubah sesuai fungsi waktu dan maksimum pressure pada dinding kanan dan dinding kiri tangki selama simulasi bisa diketahui besarnya, besar maksimum pressure pada dinding kanan tangki adalah $\mathrm{Z} 2=16513.720 \mathrm{~Pa}$ sedangkan besar pressure pada dinding kiri tangki adalah $\mathrm{Z7}=1869.362 \mathrm{~Pa}$.
B. Hasil Perhitungan Pada Tangki Membran Dengan Volume $50 \% \mathrm{H}$

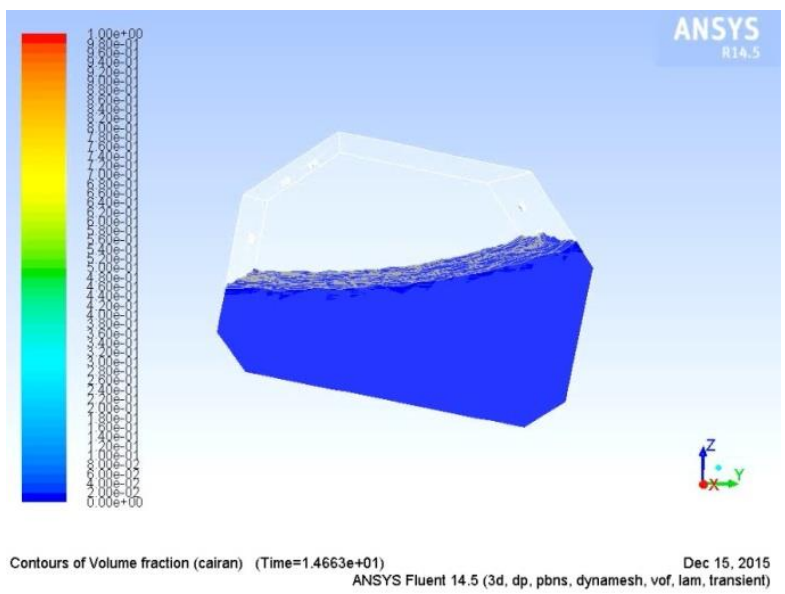

Gambar 12. Snapshot gerakan cairan LNG di dalam tangki pada filling level $50 \% \mathrm{H}$
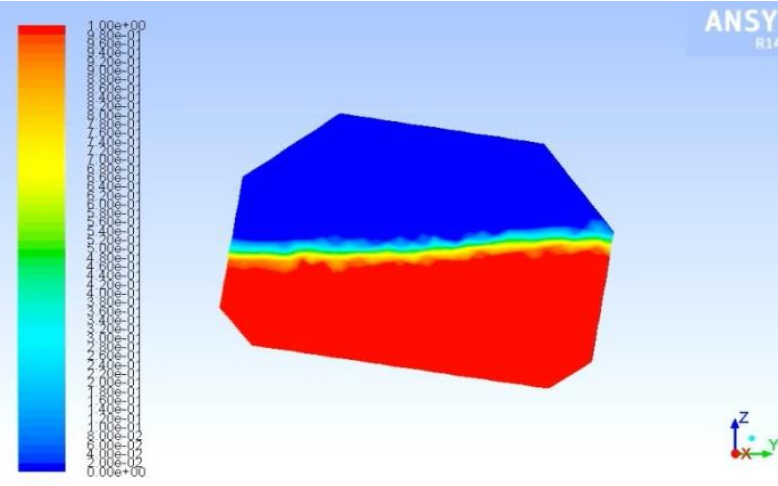

Contours of Volume fraction (cairan) (Time $=1.3924 \mathrm{e}+01)$

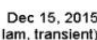

Gambar 13. Kontur dari tekanan dinamis cairan LNG di dalam tangki pada filling level $50 \% \mathrm{H}$

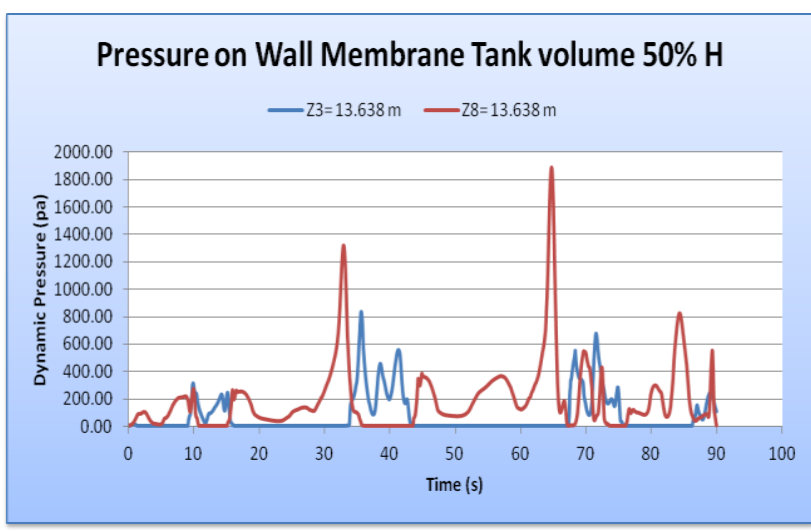

Gambar 14. Time series dari tekanan dinamis cairan LNG pada dinding node $13.638 \mathrm{~m}$ dengan filling level $50 \% \mathrm{H}$

Dari grafik diatas diketahui bahwa tekanan dinamis pada dinding kanan Z3 dan dinding kiri Z8 tangki mempunyai nilai yang berubah - ubah sesuai fungsi waktu dan maksimum pressure pada dinding kanan dan dinding kiri tangki selama simulasi bisa diketahui besarnya, besar maksimum pressure pada dinding kanan tangki adalah $\mathrm{Z3}=839.548 \mathrm{~Pa}$ sedangkan besar pressure pada dinding kiri tangki adalah $\mathrm{Z} 8=1885.410 \mathrm{~Pa}$. 
C. Hasil Perhitungan Pada Tangki Membran Dengan Volume $80 \% \mathrm{H}$

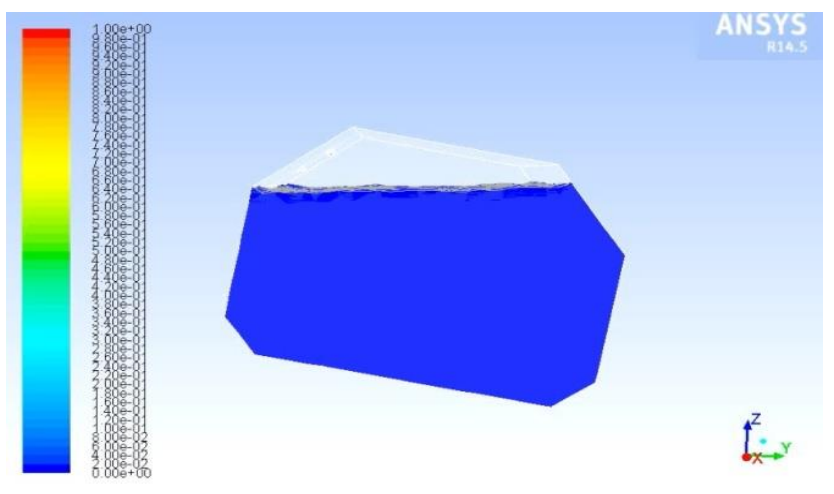

Contours of Volume fraction (cairan) (Time=2.6754e+01)
ANSYS Fluent 14.5 (3d, dp, pbns, dynamesh, vof, lam, transient)

Gambar 15. Snapshot gerakan cairan LNG di dalam tangki pada filling level $80 \% \mathrm{H}$

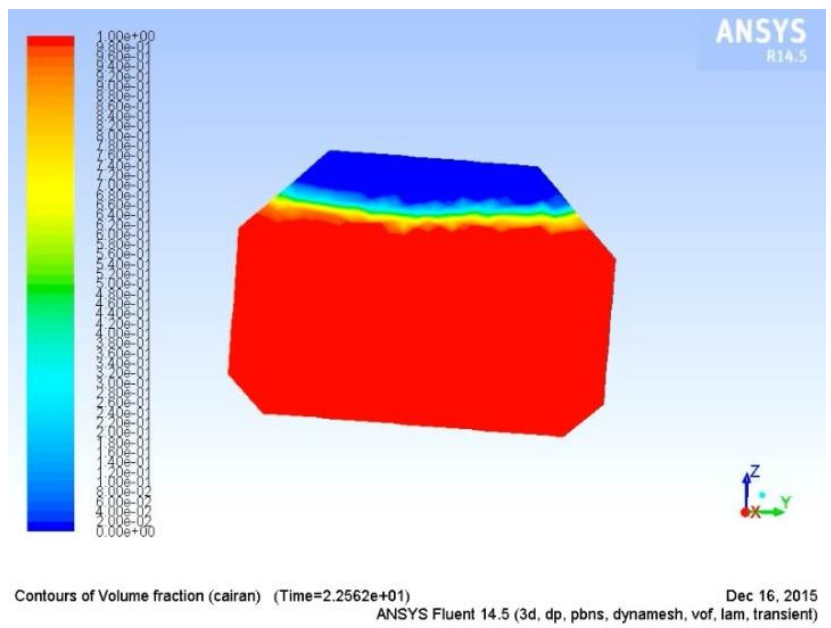

Gambar 16. Kontur dari tekanan dinamis cairan LNG di dalam tangki pada filling level $80 \% \mathrm{H}$

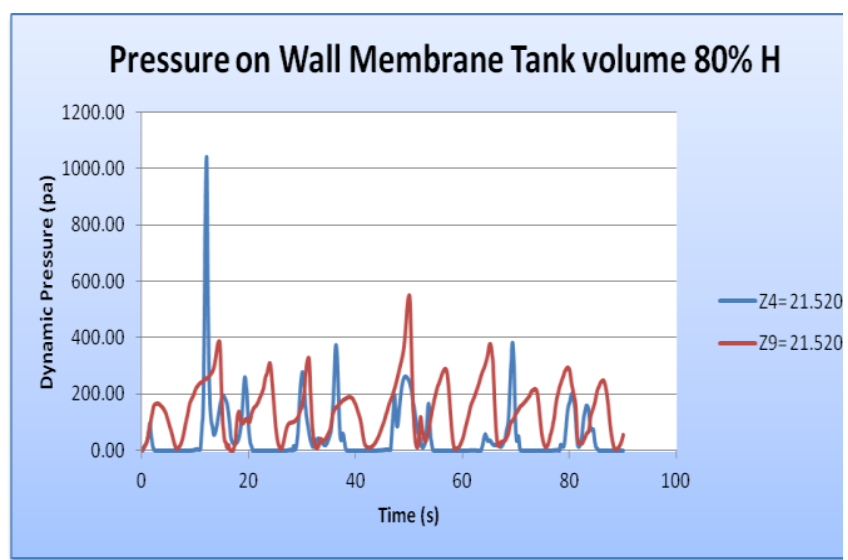

Gambar 17. Time series dari tekanan dinamis cairan LNG pada dinding node $21.520 \mathrm{~m}$ dengan filling level $80 \% \mathrm{H}$

Dari grafik diatas diketahui bahwa tekanan dinamis pada dinding kanan Z4 dan dinding kiri Z9 tangki mempunyai nilai yang berubah - ubah sesuai fungsi waktu dan maksimum pressure pada dinding kanan dan dinding kiri tangki selama simulasi bisa diketahui besarnya, besar maksimum pressure pada dinding kanan tangki adalah $\mathrm{Z} 4=1039.865 \mathrm{~Pa}$, dan sedangkan besar pressure pada dinding kiri tangki adalah $\mathrm{Z9}=548.670 \mathrm{~Pa}$.

\section{KESIMPULAN}

Berdasarkan hasil simulasi model dengan berbagai variasi dan pembahasan di atas dapat disimpulkan bahwa:

- Tekanan dinamis yang terjadi baik pada dinding kiri maupun pada dinding kanan terjadi secara tidak periodik atau tidak beraturan, walaupun gerakan tangki yang diinputkan pada simulasi adalah gerakan yang periodik/reguler.

- Ketika terjadi sloshing terutama pada filling level cairan (LNG) yang rendah yaitu $30 \% \mathrm{H}$, pressure yang terjadi pada dinding tangki lebih besar dibandingkan dengan pressure yang terjadi pada dinding tangki dengan filling level cairan yang lebih tinggi.

- Dari ke-3 variasi filling level cairan LNG, dapat disimpulkan bahwa semakin kecil filling level cairan LNG di dalam tangki, maka semakin besar tekanan dinamis yang terjadi pada dinding tangki.

\section{DAFTAR PUSTAKA}

[1] Ibrahim, R.A. (2005). Liquid Sloshing Dynamics Theory and Applications. Cambridge; Cambridge University Press.

[2] Hendratmoko, H. (2012). Study dan Eksperimen Pengaruh Bilga Keel Terhadap Gerakan Rolling (Tugas Akhir). Surabaya: Institut Teknologi Sepuluh Nopember.

[3] Bhattacharrya, R. (1978). Dynamics of Marine Vehicles. New York: Wiley Publication.

[4] Anwar, M.S. (2013). Simulasi Sloshing pada Dinding Tangki Tipe Membran Kapal LNG Akibat Gerakan Heaving dan Pitching di Gelombang Regular (Tugas Akhir). Surabaya : Institut Teknologi Sepuluh Nopember. 